\title{
What are the Challenges in Designing An Effective Personal Income Tax System?
}

\author{
Raeni $^{\mathrm{a}, *}$, Astika Sari ${ }^{\mathrm{a}}$ \\ a University of Birmingham
}

\begin{abstract}
This article aims to examine the challenges of designing individual's income tax systems in general and particularly to observe taxpayers' behaviour in developing countries. This study used case study approach to gain in depth understanding type of taxpayers' attitude towards personal income tax systems. Based on the analyses, tax behaviour, which comprises the perception of fairness and motivation to comply, attracts urgent challenges in designing effective tax on personal income in every country and mainly underdeveloped countries. Every human being in each country has their social pattern towards tax policy. When the individual perception of fairness is significant, it will harmonise the 'client and service approach' between taxpayers and governments. This condition would influence tax morale of individuals to comply with the policy and achieve high compliance rate. Therefore, it has argued that personal view of fairness and their motivation to comply with tax systems are becoming vital challenges in designing the tax policy on individual income.
\end{abstract}

Keywords: Personal Income Tax; Fairness; Tax Moral

\begin{abstract}
Abstrak
Artikel ini bertujuan untuk menginvestigasi tantangan-tantangan yang dihadapi dalam merancang sistem perpajakan untuk wajib pajak orang pribadi dan secara khusus menganalisa perilaku wajib pajak di negara-negara berkembang. Penelitian ini menggunakan pendekatan studi literatur untuk mendapatkan secara mendalam jenis perilaku wajib pajak penghasilan orang pribadi. Berdasarkan hasil analisis terkait perilaku pajak, yang terdiri dari persepsi keadilan dan motivasi untuk mematuhi memberikan tantangan tersendiri dalam merancang pajak yang berlaku atas penghasilan pribadi di setiap negara dan terutama negara-negara berkembang. Setiap individu memiliki pola yang berbeda ketika berinteraksi terhadap kebijakan pajak. Ketika persepsi individu terhadap keadilan adalah signifikan, hal itu akan menyelaraskan pendekatan 'client and service' antara pembayar pajak dan pemerintah. Kondisi ini akan memengaruhi semangat individu untuk mematuhi kebijakan dan mencapai tingkat kepatuhan yang tinggi. Oleh karena itu, asumsi bahwa pandangan individu terhadap keadilan dan motivasi untuk mematuhi sistem pajak menjadi tantangan penting dalam merancang kebijakan terhadap wajib pajak orang pribadi.
\end{abstract}

Kata kunci: Pajak Penghasilan Orang Pribadi; Prinsip Keadilan; Moral Wajib Pajak

JEL classifications: E63

\section{Introduction}

A process of designing fiscal policy is a crucial and problematic task. Tax system, especially personal income tax, plays an essential role as a central source for public spending. It also intervenes with

\footnotetext{
* Corresponding Address: Gedung L2 Lantai 1 Kampus Sekaran Gunungpati 50299. E-mail: xxr472@alumni.bham.ac. uk.
}

the public's attitude towards it. In broad terms, it is complicated to develop a powerful tax system that fits all. Each country is unique in a way that they have their characteristics, their major sources of income and their citizens' attitudes toward tax. There are many aspects to be considered by tax authorities in creating an adequate tax system, particularly on personal income tax. Miller \& Oats (2016) define personal income tax as a levy. It describes individual earnings (wages, rental or other proceeds) from business revenues. As the fiscal policy instrument, 
the functions of taxation are classified in three features; the provision of public goods, the distribution of resources and economic stabilisation. Likewise, Bird \& Zolt (2005) analysed, the main objectives of taxation are to increase government revenue and to distribute income and wealth. However, formulating the best practice to fit all purposes seems to be a challenging goal.

When designing tax system, Smith (1976) points out that there are four characteristics to be considered; equity, certainty, convenience to pay and efficiency. These fundamentals are needed in every particular area when designing a tax system. There are some essential elements to be considered such as types of income sources, subject to tax rules, the structure of tax rate, how to allocate tax burden and the effect on taxpayer behaviour (Lymer \& Oat 2015). Many alternatives have been tried to achieve an efficient design of personal income tax by changing the best practice in determining tax rate, tax base and other elements.

OECD (2012) identified that different types of tax rates' models, such as progressive, flat or regressive tax rate can be utilised as a tool in fiscal redistribution policy to reduce income inequality in all countries. In the USA for example, the government has reduced the level of tax rate while the dispersion of income tends to be rapidly widening in the few decades. Gale, Kearney \& Orszag (2015) examined that the change of individual's income tax rate in the scenario increases around $5 \%-10 \%$ in the USA and only influenced less that 0.01 of the Gini coefficient. It is also revealed that enacting a higher income tax on higher taxable income in society to trade-off decreasing number on low-income society would not affect the significant impact on the disparity between them. Le Grand (1989) examines that the failure of inequality can be explained by individual's way of thinking about social and economic equality. Even though the tax is a compulsory contribution, everyone has the option whether to comply or not to comply with their tax liability.

Moreover, from a perspective of tax based, OECD (2016) reported that the majority of OECD countries rely heavily on personal income tax which accounted for an average of $8.77 \%$ of GDP. While Denmark had the highest dependent up to $27.67 \%$ of GDP in 2014, the majority of developing countries rely less on personal income. As the example tax burden proportion of GDP for some develop- ing countries (The Heritage Foundation 2016) such as Brazil (33.4\%), Russia (34.8\%), India (16.7\%), Indonesia (11.8\%) and China (19.4\%) while the average tax revenue as a percentage of GDP as follows.

At the same time, there has been much discussion whether a tax on personal income is a failure to combat income inequality, which has diverged in the last few decades. Recent evidence shows that inequality of wealth has been effected not only in OECD countries such as the USA but also in more emerging economy countries such as Indonesia, Russia and China (OECD 2015). However, the situation is not regularly the same, because Norway for example, it relies heavily on personal income tax as well as having great equality of revenue. It even has become a country with the highest HDI for a few years.

It can be analysed that personal income tax has not meet the main objective to alleviate inequality in underdeveloped countries since it seems to be widening rapidly. In this way, there will be less distribution among the high level of earnings to the lower level of revenue through tax systems. While the richest people tend to explore more resources from the country and get more benefits in comparison to poorer people. In Indonesia, for example, tax on personal income, particularly dividend and wages, is likely to attract arbitrage. Dividend income is taxed around $10 \%$ while a tax on salaries is taxed between 5\%-30\% (PwC 2016). In this scheme, there is an opportunity for the highest level of income to substitute their wages to dividends income since the tax on dividend only about $10 \%$.

Also an opportunity not to comply with regulation because of inadequate monitoring from tax authorities. As a consequence, income on personal tax of $95 \%$ was contributed by wages and $5 \%$ from other sources of individual income. Interestingly, Oxfam (2016) quotes that Warren Buffet, the wealthiest people said that his tax payment is lower than his secretary or his cleaner. This issue also has been examined last few decades. Braithwaite (2003) identifies that around three-quarters of Australians perceived that CEO of prominent companies did not pay the fair tax of their shares. It can be analysed that tax on individual earning on salary, frequently imposed on a source is likely to provide high compliance rate. While owners of business, self-employed and entrepreneurs are bound to be reluctant to pay

Economics and Finance in Indonesia Vol. 62 No. 1, April 2016, pp. 59-66 
Table 1: Mean Tax Revenue of Proportion of GDP

\begin{tabular}{lc}
\hline Country category & Average Tax Revenue (\% of GDP) \\
\hline Low Income Countries & 13.0 \\
Lower Middle Income Countries & 17.7 \\
Upper Middle Income Countries & 20.7 \\
High Income Countries / OECD Members & 35.4 \\
Source: International Development Committee (2012)
\end{tabular}

the tax. The majority of the people believe that deducting their income to pay tax means a loss of their profit.

From those evidence, it can be seen that taxpayers in different countries have distinctive behaviour embedded. Then it can be derived a question, what challenges in designing personal income taxes effectively? Therefore, this article aims to examine the main obstacles in designing individual's income tax systems in general and particularly to observe taxpayers' behaviour in developing countries. Taxpayer's primary here refers to individual's perception of fairness and their motivation to comply with tax systems. This article is structured into two main sections: One is assessing the perception of fairness in personal income tax design in reducing the taxation income gap and two analysing the motivation to comply with paying tax in powerful personal tax income systems

\section{Literature Review}

Designing personal income tax system is a matter of tax base and tax rate schedules. Finding an ideal formulation are still remaining discussion from the part to the presents. Vickrey (1945), Mirrlees (1971), Atkinson \& Stiglitz (1976), Gordon \& Kopczuk (2014) have been concerned about tax bases. Vickrey (1945) and Mirrlees (1971) found that the ideal tax base was based on earning abilities. Also, Atkinson \& Stiglitz (1976) also argued that labour income required to be included in tax base calculation. While, Gordon \& Kopczuk (2014) examines the labour income trade-off between partners. However, taxing income is not merely about formulation between plain calculation of tax base and tax rate but also other factors embedded in this model.

Other factors could be identified from ability to pay in particular individual revenues as such explained by Smith (1976). When looking at developing coun- tries, these nations face many barriers from ability to impose tax revenue systems, either from their residents or non-residents. Lewis (1978) found that income contributed the behaviour of taxpayers in their compliance. This motivation to comply or not to comply are determined by social norms and the perceptions toward these norms such as the perception of fairness and tax morals (Kirchler 2009). In another perspective, European Commission issued a report associated with difficulties confronted in the less industries nations from domestic and international factors (COM 2010). In inside countries, developing countries have large informal sectors such as in agricultures and unregistered self-employed and irregular workers, narrow tax bases, instability of macro-economy and political, less capability of tax policy and tax administration. Moreover, the increasing number of economic integration and globalisation have contributed to barrier in taxing revenue. This factor also needs to be considered to determine attitudes of taxpayers toward tax compliance.

\section{Method}

In examining and analysis this article, qualitative method is utilised to provide better understanding in answering research question regarding challenges in developing an effective policy model on personal income taxes. Studies on tax design and tax behaviour have been undertaken by various researchers. In developing countries particularly, in remaining less. In this article, therefore, tends to focus on low-middle income countries cases. By using qualitative methods, there are six stages to conclude the results (Bryman 2014). It is begun with determining research questions, finding relevant subjects, collecting and interpreting evidence, conceptual framework and writing the finding also conclusion. 


\section{Result and Analysis}

\subsection{The Perception of Fairness}

The perception of fairness can be deemed as one of the main challenges when creating an effective personal income tax. This understanding likely leads to individual's self-awareness in the society to comply with the tax systems. Smith (1976) points out that the consideration in determining the equity of tax burden is divided into two aspects, horizontal and vertical views. In horizontal view, people who have the same taxable capacity are taxed with the same tax burden, while in vertical perspective, individual who has higher capacity pays higher tax burden. However, it remains critical that individual who earns about 40 million in two months but irregular income and person who regularly makes money until reach around 40 million in ten years would be unfair to be taxed the same amount even though they have the same taxable income. However, if the lifetime of individual is accounted for the total of tax liabilities, this is harsh to calculate a reliable measurement of the lifetime. Spicer \& Becker (1980) discover that in the same tax rate, people who perceive tax as an advantage in the fiscal circumstance tend to have higher compliance than those who see it as a disadvantage.

The judgment of fairness depends on the degree of individual choices on individual's situation. Le Grand (1989) found that people who might have the same job with different income or status have different opportunity related to taxable liability as well as the attitude towards income tax. In the progressive tax rate, the higher income can be assumed to pay higher tax rate; presumably, it generates more revenue for the government. However, in the perspective of taxpayers, people who have higher income tend to work harder and deprive their leisure time compare with other taxpayers with lower income. Their income is lower because they tend to work less and spend their time with family. This case needs to be criticised. The unfairness of that situation is likely to influence the individual when deciding whether to avoid or evade taxes. Calderwood \& Webley (1992) discover that entrepreneur and self-employed are hard-working and ambitious. When tax rates are increased, they tend to comply less with the tax authorities since it reduces their income significantly. While in the case of less oppor- tunity to avoid, Loewenstein \& Issacharoff (1994) find that self-employed become less hard-working. It can be argued that higher tax rate may discourage people to work as well as being honest to comply.

Individual tax perception in fairness also tends to be influenced by their satisfaction towards their government. The government could be seen as providing services to the society. A study conducted by Kirchler (1997) examines that Australian taxpayers argue that government needs to spend more public fund on education, public health, science and research as well as on preserving art, culture or military defense. Brazil, as an illustration, has implemented effective policies that emphasize more tax spending on education, health and cash transfer to approximately $25 \%$ of poor households. This policy can reduce inequality up to roughly five points as well as create more jobs which lead to more tax revenue. The satisfaction of services provided by government could determine the relationship between government or tax authorities and taxpayers as 'cops and robbers' or 'service and client' approach. Andrews (2003) suggests that governments should be aware of the existence of society as customers. Building trust with customers or citizens such providing the best services to client needs to be considered in gaining the perception of fairness between various levels of taxpayers. In contrast, Kirchler (2009) views that in command and control approach, individual is seen as self-interest maximization who tend to avoid and evade tax as higher as possible.

The relationship between tax authorities can be developed through another fairness area, such as procedural justice. Wallschutzky (1984) identifies that the perception of procedural justice can be affected by the interaction between tax officers and taxpayers such as the time spent to pay tax and the effort needed to pay as well as the treatments for it. However, Sheffrin (2013) argues that procedural justices not only concern about the output of tax policies but also the engagement of taxpayers in designing tax systems. For ensuring taxpayers' compliance, the voice of every part of societies needs to be considered in determining the best approach to increase the dignity of citizens. In the case of low and lower-middle-income countries, the approach of procedural justice seems to provide an opportunity to tax employees in the informal sector with a low level of compliance. OECD (2015) reported that $59.6 \%$ of 114.6 million Indonesians' are workers of informal sectors. If the informal sec- 
tors can be involved in designing personal income tax and can be treated respectfully, the existence of informal sectors can generate more revenue for governments.

An individual's view of fairness is differently related to the attitude towards tax liability. Strümpel (1966) posits that the level of individual's compliance can be affected by their behaviour and perception towards tax system the understanding of equality in the tax regime. As a consequence, the fairness of tax systems perceives by societies tends to affect the way of thinking about inequality of income. According to Lymer \& Oats (2015), a tax is enacted as the source of funding for four primary purposes. The aims are economic stability, regulatory objective, increasing the quality of human life and delivering public goods. If personal income tax proportion to GDP is small, it could not provide significant impact to society because the lower level of compliance means that it could not cover government spending and the general goal could not be achieved. Therefore, income tax from an individual can give excellent opportunities to generate public revenue as well as increase equality.

\subsection{Motivation to comply}

Another critical challenge when developing tax system is the motivation of taxpayers to comply with tax regimes. According to Bărbuţămişu (2011), the conformity behaviour of taxpayers is influenced by economic and non-economic factors. The economic factor consists of the level of actual income, tax rates, tax benefits, penalties, tax audits, fines and audit probability. The non-economic factor includes attitude toward tax, personal, social and national norms, and perceived fairness of tax system. There are also some other components that affect taxpayer compliance, namely confidentiality (Laury \& Wallace, 2005), social behaviour and enforcement (Davis, Hecth \& Perkins, 2003). A government needs to realize that the economic factor in the form of financial incentives such as tax rate, penalty and administration fines should not be considered as the primary focus to make taxpayer comply with the tax obligation. Although the government has the legitimacy to encourage their citizens to fulfill its tax compliance, taxpayers should have the opportunity to manage their compliance. Therefore, motivation to comply needs to be considered when designing fiscal policy as well as tax moral of societies, which is translated into intrinsic motivation.

In a tax morale perspective, research indicates that there is a high correlation between tax compliance and tax morale in both industrialized and developing countries (OECD 2013). According to Torgler \& Schneider (2009), morale is an individual intrinsic motivation which is a voluntary act to obey and pay tax for the sake of a successful country's development. When each taxpayer has a good morale in complying with the tax system, it is likely to improve tax revenue as well as other objectives of fiscal policy, such as enough sources of public spending. Tax morale can be explained as a condition where the taxpayer is honest in paying taxes. While tax compliance can be defined as a state where a taxpayer has already complied with all of the taxpaying requirements. There are a few aspects that affect tax morale according to Feld \& Frey (2002). Firstly, there is a perception of honesty. Secondly, tax authority's helpfulness with regards to meeting with the tax regulation. Then the high level of trust in government and mutual respect between the taxpayer and tax officials.

The socioeconomic perspective needs to be considered in drawing better pictures of the real condition on individual taxpayers. A better understanding of the subject leads to superior strategy in designing tax systems as well as in increasing the number of tax compliance. There are also several factors influencing tax moral such as support for democracy, age, trust in government, female, religious and education degree. In Asia, for instance, the confidence of citizens in the government have a significant impact on the tax morale of the taxpayers (OECD 2013). As a consequence, individual tends to evade or avoid tax systems since there is no trust in the government. Furthermore, when the level of taxpayer's trust and confidence increases, it may lead to an excellent tax compliance. The high degree of reliance towards tax official, such as shown by Austria and Switzerland taxpayers, is mainly caused by an effective tax regulation and system execute by honest and professional tax officials. It is identified by Torgler \& Schneider (2005); morale factor has a significant influence on the tax compliance factor in Austria. The morale factor comes from the existence of trust and pride variable toward tax authority. Moreover, this factor becomes a crucial and a significant factor for Austria to shape a better tax compliance for a taxpayer. Therefore, a mutual rela- 
tionship between government, tax authority and taxpayer need to be maintained and flourished through an efficient and well-performed action as well as creating a positive social atmosphere.

In our society, there is a social pattern where a group of people will likely to abide any social norm as long as they believe that the other groups are also complying with it, and vice versa. Incompliance behaviour performed by an individual will affect others because that kind of action will create an opportunistic behaviour in a disadvantage way such as tax evasion. This type of opportunistic behaviour tends to arise when there is a weak undetected supervision by the tax authority.

When fraud keeps being committed by the taxpayer and is seen as "typical conduct" in a tax system, the tax morale and compliance will perform poorly. Another example is the self-employed citizens who tend to have lower tax morale than full-time employees. The opportunity for full-time employees to not to comply with tax regulation is limited as the income is deducted by their employer. However, tax morale related to self-employed is not always the same since Strümpel (1969) found that the tax morale in England was relatively high while in other European countries had a lower level of tax morale. Although, when the German government enacted a coercive tax enforcement law, the tax morale of the citizen was also comparatively small, while in England, the government focused on giving more attention and respect to societies rather that taking an active control.

A type of tax policy for the purpose of increasing the tax morale between one country to another seems to be different depending on the type of taxpayers' characteristics. Tax morale is not an independent factor and might be driven by the environment in which the taxpayers live. For illustration, a tax that is collected by religious institution as obligatory tax, but there is no significant enforcement, this tax has a significant tax compliance (Dwenger et al. 2014). In contrast, Luttmer \& Singhal (2014) examine that in a country with strict enforcement, tax morale is seen as an important aspect of society. While a country with a lack of law enforcement, tax compliance may not be deemed necessary. When an individual has a self-awareness to comply, they might feel ashamed if they do not pay taxes. It happened in Australia where tax compliance become a voluntary obedience. Torgler \& Murphy (2004) find out that tax morale plays a crucial role in accordance behaviour such as in Australia, which enacted a voluntary respect and self-assessment in paying tax, and taxpayers tend to comply with the regulation.

Tax morale is an intrinsic part of the motivation to deliver while there are other factors, which determine tax compliance of personal income tax. According to Alm \& Torgler (2011) analyse, the taxpayer is motivated to meet the tax obligation only because of the fear of getting penalties, tax fines, tax inspection and tax rates. The aversion towards individual's risk seems to be dissimilar. Braithwaite, Murphy \& Reinhart (2007) examine that there are five elements of motivation; commitment, capitulation, resistance, disengagement and game playing.

Commitment occurs when taxpayers are willingly want to fully involved in understanding the system, benefits, procedure, vision and mission of the regulated tax regime. In the capitulation element, there is no level of involvement to the tax authority and taxpayers comply to pay all of their taxes such as income tax, corporate tax and consumption tax. When taxpayers experience an injustice system such as unfair income tax, they will confront openly to the tax authority. This kind of action is the resistance element. For the disengagement and gameplaying elements, it will be executed by the taxpayer when there is no trust factor between them. For instance, when tax authority is seen to be applying unfair tax system (tax rates, penalties and fines, tax benefits) or worse tax authority conducting criminal tax activity (corruption), then the disengagement element occurs where the taxpayer will separate psychologically with tax administration. Another situation, for example, is when taxpayers are aware that they can cooperate with the tax authority into doing criminally act manipulate the tax system, then this kind of practices constitutes as the game-playing element.

Motivational attitudes could also be seen as a social signal sent by the taxpayer to the tax authorities as a social communication tool to identify the social distance between the taxpayer and fiscal officers. The social signal is created by using the social distance between the taxpayers and the tax authorities (Kirchler 2009). When tax authorities could not understand and would not pay attention to the demands made by taxpayers, it ultimately causes the taxpayer to be ignorance and fearless of complying with tax liability. The effectiveness of tax reg- 
ulations can be seen through the social distance condition. When the distance is getting further, it shows that the tax rules are still not suitable and representative to the taxpayer's interest regarding fair tax collection, reasonable tax rates, and the simplicity of tax collection procedures. According to Braithwaite (2003), the social distance created by the taxpayer and tax authority can be identified by using the motivational posture. The social distance explains the influence position between the tax administrators and the taxpayers. When the distance is widening, it means that the tax authority did not understand or giving enough attention to the demand and interest of the taxpayers on matters such as unfair and unsuitable tax rates, tax benefits, or any consequences that taxpayer experienced will lead to a higher social distance. Consequently, the taxpayer will not comply and show disobedience to the tax authority and its regulation. Therefore, the success of the relationship between taxpayer and tax administration can be seen through the social distance.

When a good mutual relationship between the taxpayer and tax authority existed, it consequently will give a solution to cope with the issue of social distance. Synchronising the taxpayer's interest in the tax authority's interest and its taxation regulation will create a harmonise relationship. Therefore, trust, pride, respectful, fair, professional and liable in taxpayer and tax officials need to be strengthened. In return, the motivational posture factor of commitment and capitalization will improve and will create adequate tax compliance. It can be identified that taxpayer's compliance is not based only on economic factors but also non-economic factors such as motivation, social norm and etiquette. As previously mentioned, the motivational posture factor plays a crucial role in shaping tax compliance and relationship between taxpayer and tax authority.

\section{Conclusion}

Based on the analyses above, tax behaviour, which comprises the perception of fairness and motivation to comply, attracts urgent challenges in designing effective tax on personal income in every country and mainly underdeveloped countries. Personal income tax system can be seen as powerful policy when achieving the objectives of tax on individual income, such as the source of revenue for public spending with high compliance rate as well as distribute income to societies. However, the best design would be ineffective without considering the subject. Every human being in each country has their social pattern towards tax policy. When the individual perception of fairness is significant, it will harmonize the 'client and service approach' between taxpayers and governments. This condition would influence tax morale of individuals to comply with the policy and achieve high compliance rate. Therefore, this article has argued that personal view of fairness and their motivation to comply with tax systems are becoming vital challenges in designing the tax policy on individual income.

\section{References}

[1] Alm, J, \& McKee, M 2004, 'Tax Compliance as A Coordination Game', Journal of Economic Behavior \& Organization, vol. 54, no. 3, pp. 297-312.

[2] Alm, J, \& Torgler, B 2011, 'Do Ethics Matter? Tax Compliance and Morality', Journal of Business Ethics, vol. 101, no. 4, pp. 635-651.

[3] Andrews, M 2003, 'New Public Management and Democratic Participation: Complementary or Competing Reforms? A South African Study', International Journal of Public Administration, vol. 26, no. 8-9, pp. 991-1015.

[4] Atkinson, AB, \& Stiglitz, JE 1976, 'The Design of Tax Structure: Direct Versus Indirect Taxation', Journal of Public Economics, vol. 6, no. 1, pp. 55-75.

[5] Bahl, R 2004, 'Reaching the Hardest to Tax: Consequences and Possibilities' in Taxing the Hard-to-Tax: Lessons from Theory and Practice, eds. J Alm, J Martinez-Vazquez \& S Wallace, Elsevier, Amsterdam, pp. 337-355.

[6] Bărbuţămişu, N 2011, 'A Review of Factors for Tax Compliance', Economics and Applied Informatics, vol. 17, no. 1, pp. 69-76.

[7] Bird, RM, \& Zolt, EM 2005, 'The Limited Role of the Personal Income Tax in Developing Countries', Journal of Asian Economics, vol. 16, no. 6, pp. 928-946.

[8] Braithwaite, V 2003, 'Perceptions of Who's not Paying Their Fair Share', Australian Journal of Social Issues, vol. 38, no. 3, pp. 335-362.

[9] Braithwaite, V, Murphy, K, \& Reinhart, M 2007, 'Taxation Threat, Motivational Postures, and Responsive Regulation', Law \& Policy, vol. 29, no. 1, pp. 137-158.

[10] Bryman, A 2015, Social Research Methods, 5th ed., Oxford University Press, Oxford.

[11] Calderwood, G, \& Webley, P 1992, 'Who Responds to Changes in Taxation? The Relationship Between Taxation and Incentive to Work', Journal of Economic Psychology, vol. 13 , no. 4, pp. 735-748.

[12] COM (2010) Communication from the Commission to the European Parliament, the Council AND THE European Economic and Social Committee - Tax and Development Cooperating with Developing Countries on Promoting Good Governance in Tax Matters SEC(2010)426. Available from: <http://eur-lex.europa.eu/legal-content/ 
EN/TXT /PDF / ?uri=CELEX : 52010DC0163\& from=EN > . March 15 2016].

[13] Davis, JS, Hecht, G, \& Perkins, JD 2003, 'Social Behaviors, Enforcement, and Tax Compliance Dynamics', The Accounting Review, vol. 78, no. 1, pp. 39-69.

[14] Deegan, C, \& Unerman J 2011, Financial Accounting Theory, European Edition of 2nd Revised Edition, McGraw-Hill Education, Berkshire.

[15] Dwenger, N, Kleven, H, Rasul, I, \& Rincke, J 2014, Extrinsic and Intrinsic Motivations for Tax Compliance: Evidence from a Field Experiment in Germany, [Unpublished paper], May.

[16] Feld, LP, \& Frey, BS 2002, 'Trust Breeds Trust: How Taxpayers are Treated', Economics of Governance, vol. 3, no. 2, pp. 87-99.

[17] Gale, WG, Kearney, MS, \& Orszag, PR 2015, 'Would a Significant Increase in the Top Income Tax Rate Substantially Alter Income Inequality?', Economic Studies at Brookings. Available from: <http://tpcprod.urban.org/UploadedPDF / 2000425-would-top-income-tax-alter-incomeinequality . pdf>. [15 March 2016].

[18] Gordon, $\mathrm{RH}$, \& Kopczuk, W 2014, 'The Choice of the Personal Income Tax Base', Journal of Public Economics, vol. 118, pp. 97-110.

[19] International Development Committee 2012, 'Tax in Developing Countries: Increasing Resources for Development', Fourth Report of Session 2012-13. Available from: <http://www.publications.parliament.uk/ $\mathrm{pa} / \mathrm{cm} 201213 / \mathrm{cmselect} / \mathrm{cmintdev} / 130 / 130 . \mathrm{pdf}>$. [15 March 2016].

[20] Kirchler, E 1997, 'The Burden of New Taxes: Acceptance of Taxes as a Function of Affectedness and Egoistic Versus Altruistic Orientation', The Journal of Socio-Economics, vol. 26, no. 4, pp. 421-437.

[21] Kirchler, E 2009, The Economic Psychology of Tax Behaviour, Cambridge University Press, Cambridge.

[22] Laury, S, \& Wallace, S 2005, 'Confidentiality and Taxpayer Compliance', National Tax Journal, vol. 58, no. 3, pp.427438.

[23] Le Grand, J 1989, The Strategy of Equality, Allen \& Unwin, London.

[24] Lewis, A 1978, 'Perceptions of Tax Rates', British Tax Review, 6, pp. 358-366.

[25] Loewenstein, G, \& Issacharoff, S 1994, 'Source Dependence in the Valuation of Objects', Journal of Behavioral Decision Making, vol. 7, no. 3, pp. 157-168.

[26] Luttmer, EFP, \& Singhal, M 2014, 'Tax Morale', Journal of Economic Perspectives, vol. 28, no. 4, pp. 149-168.

[27] Lymer, A, \& Oats, L 2015, Taxation: Policy and Practice, 22nd Edition. CPI Group (UK) Ltd, Croydon.

[28] Miller, A, \& Oats, L 2016, Principles of International Taxation, 5th Revised Edition. Bloomsbury, West Sussex.

[29] Mirrlees, JA 1971, 'An Exploration in the Theory of Optimum Income Taxation', The Review of Economic Studies, vol. 38,no. 2, pp. 175-208.

[30] OECD 2012, 'Income Inequality and Growth: The Role of Taxes and Transfers', OECD Economics Department Policy Notes, No. 9. Available from: <http: //www.oecd. org/dataoecd/2/13/49417295.pdf >. [14 March 2016].

[31] OECD 2013, What Drives Tax Morale?, Tax and Development Program. Available from: <http: //www. oecd.org/ ctp/tax-global/TaxMorale_march13.pdf>. [14 March 2016].

[32] OECD 2015, Income Inequality and Labour Income
Share in G20 Countries: Trends, Impacts and Causes, International Labour Organization - International Monetary Fund - Organisation for Economic Co-operation and Development - World Bank Group. Prepared for the G20 Labour and Employment Ministers Meeting and Joint Meeting with the G20 Finance Ministers, Ankara, Turkey, 3-4 September 2015. Available from: <http: //www . oecd. org/g20/topics/employment-and-social-policy/ Income-inequality-labour-income-share.pdf $>$. [14 March 2016].

[33] OECD 2016, Tax on Personal Income (Indicator), doi: 10.1787/94af18d7-en. Available from: <https: //data.oecd.org/tax/tax-on-personal-income.htm>. [14 March 2016].

[34] Oxfam 2016, 'An Economy for the 1\%: How Privilege and Power in the Economy Drive Extreme Inequality and How This can be Stopped', 210 Oxfam Briefing Paper. Available from: <https://www.oxfam.org/ sites/www. oxfam.org/files/file_attachments/ bp210-economy-one-percent-tax-havens-180116-en_ $0 . p d f>$. [17 March 2016].

[35] PwC 2016, Indonesian Pocket Tax Book 2016, PricewaterhouseCoopers International Ltd. Available from: <https://www.pwc.com/id/en/pocket-tax-book/ ptb-2015-final-eng.pdf>. [15 March 2016].

[36] Sheffrin, SM 2013, Tax Fairness and Folk Justice, Cambridge University Press, New York.

[37] Smith, A 1976, An Inquiry into the Nature and Causes of the Wealth of Nations, Indian-Verlag, Munchen.

[38] Spicer, MW, \& Becker, LA 1980, 'Fiscal Inequity and Tax Evasion: An Experimental Approach', National Tax Journal, vol. 33, No. 2, pp. 171-175.

[39] Strümpel, B 1966, 'The Disguised Tax Burden Compliance Costs of German Businessmen and Professional', National Tax Journal, vol. 19, no. 1, pp. 70-77.

[40] Strümpel, B 1969, 'The Contribution of Survey Research to Public Finance' in Quantitative Analysis in Public Finance, ed. AT Peacock, Praeger, New York, pp. 14-32.

[41] The Heritage Foundation 2016, 2016 Index of Economic Freedom, Explore the Data. Available from: <http: //www . heritage.org/index/explore?view=by-variables $>$. [10 May 2016].

[42] Torgler, B, \& Murphy, K 2004, 'Tax Morale in Aus tralia: What Shapes It and Has It Changed over Time?', CREMA Working Paper Series 2004-04, Center for Research in Economics, Management and the Arts (CREMA). Available from: <http : //www . crema-research . ch/papers/2004-04.pdf>. [10 March 2016].

[43] Torgler, B, \& Schneider, F 2005, 'Attitudes Towards Paying Taxes in Austria: An Empirical Analysis', Empirica, vol. 32, no. 2, pp. 231-250.

[44] Torgler, B, \& Schneider, F 2009, 'The Impact of Tax Morale and Institutional Quality on the Shadow Economy', Journal of Economic Psychology, vol. 30, no. 2, pp. 228-245.

[45] Vickrey, W 1945, 'Measuring Marginal Utility by Reactions to Risk', Econometrica, vol. 13, no. 4, 319-333.

[46] Wallschutzky, IG 1984, 'Possible Causes of Tax Evasion', Journal of Economic Psychology, vol. 5, no. 4, pp. 371384.

[47] World Bank 2015, 'Indonesia's Rising Divide', Available from: <http://pubdocs.worldbank.org/ pubdocs/publicdoc/2016/4/16261460705088179/ Indonesias-Rising-Divide-English.pdf>. [10 March 2016]. 